\title{
ILLEGALLY OBTAINED EVIDENCE IN ESTADO DE MEXICO. AN ANALYSIS OF THE LEGAL INSTITUTION AND THE JUDICIAL INTERPRETATION
}

\author{
LA PRUEBA ILÍCITA EN EL ESTADO DE MÉXICO. UN ANÁLISIS \\ DE SU REGULACIÓN Y DE LA INTERPRETACIÓN JUDICIAL
}

\author{
PaOla I. De la Rosa Rodríguez ${ }^{1}$
}

\begin{abstract}
Although the change to an adversarial system has made a significant progress in Estado de Mexico, legal provisions do not procure enough guidance to judges and legal counsellors on how to proceed with the exclusionary rule, persisting important doubts in this regard. This article seeks to evaluate if judges thoroughly respect the human rights of the accused, at the expense of the victim's right to obtain the truth. At the same time, this paper intends to answer if judges consider the seriousness of the crime while evaluating the specific cases for which they can admit illegally obtained evidence ${ }^{2}$. Among the survey findings are that there is a considerably rhetorical knowledge of the illegal evidentiary material, however, there exists a predisposed lawless criminal investigation for violent and organized crime which makes prosecutors present this type of evidentiary material in court. The common consequence, if defense counsellors present arguments against this information, is that judges exclude it from the legal process and several criminals remain unpunished.
\end{abstract}

Keywords: Adversarial system, exclusionary rule, illegally obtained evidence, rights of the accused.

RESUMEN: Aunque la transición al sistema acusatorio ha mostrado un avance significante en el Estado de México, de la interpretación de la norma se advierten varias dudas sobre el tema de la prueba obtenida ilícitamente. Este artículo analiza si los jueces deciden respetar los derechos humanos del acusado, por encima de aquellos de la víctima a obtener la verdad. Al mismo tiempo, este estudio evalúa si los jueces consideran la gravedad del delito cuando resuelven admitir o rechazar prueba obtenida ilícitamente. De la encuesta realizada encontramos que no obstante exista un conocimiento teórico de los medios de convicción ilícitos, la investigación criminal de delitos violentos y delincuencia organizada se realiza sin apego a la norma. En forma subsecuente, y en el caso de que la defensa se oponga a dichos medios de convicción, los jueces excluyen estas probanzas orientando el procedimiento hacia la impunidad.

Palabras clave: Sistema adversarial, prueba ilícita, prueba obtenida ilícitamente, derechos del acusado.

1 Doctora en Derecho, Universidad Autónoma de Nayarit. Research Professor UASLP Faculty of Law, México. Postal Address: Mariano Otero no. 923 col las Águilas San Luis Potosí, S.L.P. C.P. 78260, México. E-Mail: paorosro@hotmail.com

2 Illegally obtained evidence is a term used to refer to pieces of evidence obtained, transported or practiced in violation of human rights. It is also called exclusionary rule. 


\section{INTRODUCTION}

The main questions this paper attempts to answer are as follows: Does the regulation of the exclusionary rule in Estado de Mexico provide a clear guidance to legal counsellors and the judiciary as to what to apply when there is a divergence between the protection of the accused rights and the search of the truth? Do judges consider the rights of the accused are more important than those of the victims?

This study focused on three objectives. The first goal was to analyze the legal stipulations regulating the exclusionary rule ${ }^{3}$ in Estado de Mexico while exploring the interests protected in legal instruments governing the illegally obtained evidence. The second objective was to find the way judges interpret the existing rules and examine their experiences while applying the existing laws. With that purpose, we evaluated magistrates's perceptions and experiences in court. Finally, it presents a statistical analysis on the interpretation and the effects derived from the legal reforms at the same time it lays the ground for new pieces of research on the relation of illegally obtained evidence and the search of the truth in criminal cases.

\section{METHODOLOGY}

This paper describes the subject of the illegally obtained evidence by analyzing the regulations governing criminal procedures in Mexico. The methodology approach of the manuscript consists of analysis of the law, including the method of conceptual analysis of a legal figure. Specifically, this study analyzed the existing exclusionary rule framework in order to understand the purpose of this legal institution.

Secondly, it was necessary the use of the evaluative research method to distinguish the thinking patterns of the judicial officers. Accordingly, it was conducted a survey to determine if they prefer the protection of human rights over the search of the truth, taking into account the two of them cannot be obtained simultaneously in all cases. This allowed us to understand the role of illegally obtained evidence in the adversarial system in Estado de Mexico. Finally, the analysis of statistical indicators was complemented by the insertion of information obtained out of surveys.

The participants of this study were a group of total seventy judges working in Estado de Mexico, one of the thirty two states in the Mexican Republic. The survey was conducted to the total number of judges applying the adversarial system at the time of the study. In other words, $100 \%$ of the interviewed judicial officers worked for the new model of criminal justice in Mexico. The judges chosen to answer the questionnaire were the ones applying the adversarial system at the time of the study.

The instrumentation of this investigation was through the application of questionnaires, distributed during last months of 2014. Additionally, the Federal Constitution and the Criminal Procedure Code were also analyzed.

\footnotetext{
${ }^{3}$ A rule of evidence that excludes or suppresses evidence obtained in violation of a defendant's constitutional rights.
} 


\section{BACKGROUND}

The criminal procedure constitutional reform implementing an adversarial system in Mexico passed in 2008, as a response to critical social demands. The constantly recurring social complaints include judicial procedure's delays, absence of alternative dispute resolution mechanisms, lack of public access to judicial procedures, nonexistence of methods to address the harm caused to victims and offering them compensation, and discrimination to low income criminals ${ }^{4}$. Beyond that, MENESES \& QuintanA argue that the percentage of criminal offences not reported to the prosecuting authorities in 2013 amounted $93.8 \% 5$ and LeCUONA suggests that $97.9 \%$ of crimes are not punished in Mexico ${ }^{6}$.

LECUONA's research revealed a constant infringement of human rights during criminal investigations ${ }^{7}$. In addition, the Supreme Court of Justice stated that having suffered physical violence at the time of the arrest did not rest value to the confession of the accused, if it is confirmed by other pieces of evidence ${ }^{8}$. It was also prevalent to observe abusive techniques by state authorities contrary to the law. MENDOZA documented that police officers conducted arbitrary detentions and interrogation methods included torture and cruel treatment, violating the right of the accused not to be forced to declare against himself ${ }^{9}$.

As sustained by LARRAGOITI, according to a principle called "immediacy"- commonly used in the inquisitorial system -, the first suspect depositions are worth more than the ones given at a later stage in the procedure ${ }^{10}$. Besides, self-incrimination depositions are obtained without a defense lawyer and without being informed of the right to remain silent. Furthermore, in the previous system, criminal investigation activities by the prosecution had full probative value ${ }^{11}$.

Under these circumstances, the inquisitorial system, enforced in Mexico for more than five centuries ${ }^{12}$, shaped the judicial officer's criteria and judges would value information obtained in violation of the human rights. In such conditions, the delivery of justice would give rise to convicting sentences. This ideology prevailed, infringing human rights, comprising arbitrary detentions, acts of torture to obtain confessions, self- incrimination statements and illegally obtained evidence.

The criminal procedure reform also involves a strict nullity of illegal information for having been collected in violation of fundamental human rights ${ }^{13}$. In this sense, there are some other aspects - beyond the understanding of the legal provisions- that ought to be reviewed and known.

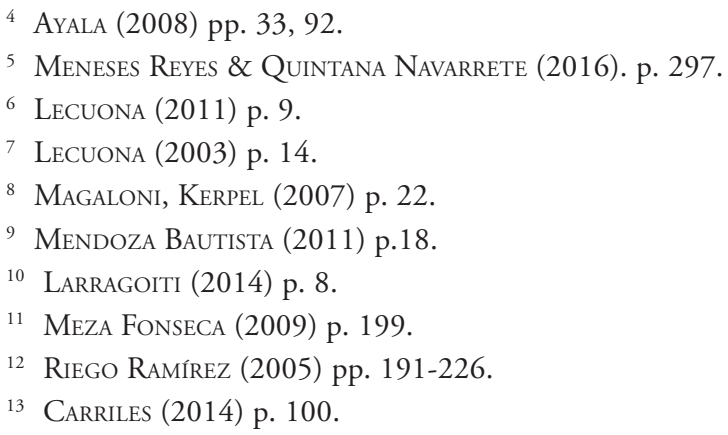




\section{LEGAL FRAMEWORK}

Estado de Mexico passed the Criminal Procedure Code that implemented the adversarial system in 2009 and with that, it was necessary a deep legal training to judges district attorneys and counsellors ${ }^{14}$. Considering that it was mandatory by the time this paper was being written, it is important to analyze its content since it would remain applicable until the creation of National Code and its enforcement by $2016^{15}$.

From this angle, that first legal instrument provides that any information will only have probative value if it was obtained and practiced by any legal means. It respects the presumption of innocence that as CRUZ mentions, implies that evidence used to override it must be legal. In addition, the code includes the right to declare or to remain silent ${ }^{16}$. Self-incrimination is also prohibited and the code establishes that any search and seizure will only be carried out with a warrant. It prohibits torture and other cruel, inhuman or degrading treatment ${ }^{17}$. It also prohibits evidentiary material obtained by these methods ${ }^{18}$.

In light of these findings, the code strongly protects the accused human rights, a deeper insight however, deduces that this is not completely true. For instance, it authorizes the activities of undercover agents, among criminal investigation methods. This article argues that they violate the right of the accused not to be misled in order to obtain from him an inculpatory statement that can be used during the legal procedure. Furthermore, violating the expectation of privacy, electronic surveillance including the installation of microphones, cameras, pagers and satellite devices is also permitted in private places in order to obtain information regarding the commission of a crime and this information can be considered and valued by a judge ${ }^{19}$.

Finally, after a revision of this code we found that it also regulates body inspections when they are ordered by the prosecutor or the judge when having a serious suspicion and when they are practiced privately and by qualified personnel of the same gender.

After analyzing the Constitution governing Estado de México we contend that it assures the rights and individual freedoms of human beings. It also indicates that the accused enjoys the rights established by the Federal Constitution, the Criminal Code and the Criminal Procedures Code. Moreover, having in mind that article 20 of the Federal Constitution stipulates nullity of the illegally obtained evidence, it is clear that it is a right of the accused, and it must not be admitted in Court.

As of 2008, the presumption of innocence of human beings was recognized by the Federal Constitution ${ }^{20}$ stating that only legally obtained evidence can be used to override this presumption. Additionally, in consistence with the Constitution, law enforcement of-

\footnotetext{
14 Delgado Carbajal (2013) p. 92.

15 García Ramírez (2014) p. 1170.

16 Cruz Pastrana (2016) p. 44.

17 Código de procedimientos penales para el Estado de México. Article 12.

18 Código de procedimientos penales para el Estado de México. Article 153.

19 According to article 451, wire-tapping is allowed when the General Attorney so requests to the federal authorities.

${ }^{20}$ Brewer (2014) p. 78.
} 
ficers need to fulfill some requirements for certain criminal investigation activities such as the need of a warrant to enter a suspect's home and obtain evidence ${ }^{21}$.

\section{JUDGE'S OPINION SURVEY}

Once the Mexican ordinance in relation to illegally obtained evidence has been reviewed, this study also contributes to report the results of a judge's opinion survey on this topic.

The purpose of the survey is to analyze the regulations through the experiences and interpretation of those who apply the law. We obtained opinions on the weigh judges give to criminal investigation and the weigh they give to the protection of individual rights of the accused, and other estimations that will allow us to approach and comprehend the pronouncements delivered in court.

Law itself does not contain the response to such questions, in that light, it was necessary to obtain judges' impressions towards the law and the way they interpret and apply the current legal instruments regulating illegally obtained evidence. Estado de Mexico was chosen to conduct the interview as long as it was one of the first Mexican states to implement the adversarial system in the country and is one of the states whose judicial officers have more expertise with the new legal institutions and procedures.

The survey was conducted to seventy judicial officers. The number of interviews applied was representative having in mind that according to information provided by Administración de los juzgados del sistema penal acusatorio in charge of managing the adversarial system state courts, by june 2015 it was necessary to have ninety trained judges in this state to apply the new laws. The poll was applied the last months of 2014. The judicial districts and number of judges answering the survey are as follows:

21 Constitución Federal de los Estados Unidos Mexicanos. Article 14. 
De la Rosa Rodríguez, Paola I. " "Illegally obtained evidence in estado de Mexico..."

\section{TABLE 1}

Number of surveys applied by judicial district

\begin{tabular}{|l|c|}
\hline \multicolumn{1}{|c|}{ Judicial district } & Number of surv eys applied \\
\hline Chalco & 3 \\
Cuautitlán & 2 \\
\hline Ecatepec de Morelos & 14 \\
Jilotepec & 1 \\
Lerma & 2 \\
\hline Nezahualcóyotl & 9 \\
Temascaltepec & 1 \\
Tenancingo & 1 \\
\hline Tenango & 1 \\
Tlanepantla de Baz & 20 \\
\hline Texcoco & 6 \\
Toluca & 8 \\
Otumba & 1 \\
\hline Zumpango & 2 \\
\hline
\end{tabular}

This section presents findings of the analysis on the impact that the exclusionary rule regulations have among judicial officials.

Question one. In your opinion, is evidence obtained and/or practiced respecting the constitutional regulations and international treaties?

\section{GRAPHIC 1}

Is evidence obtained respecting constitutional and international regulations?

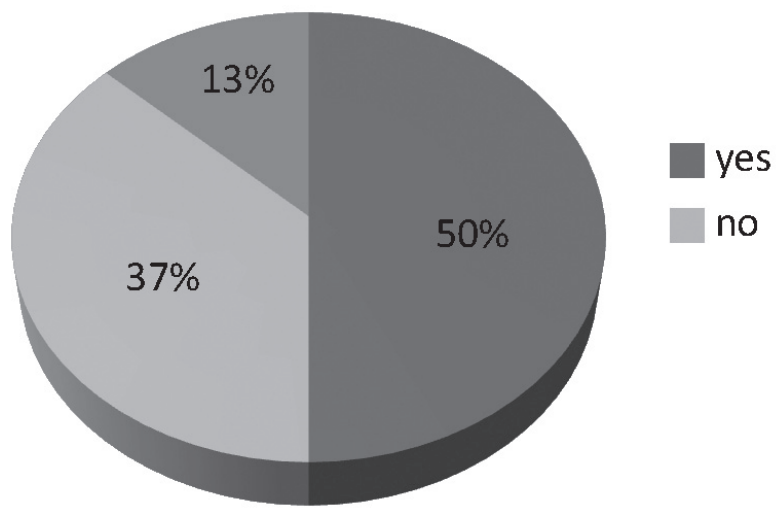

Thirty five judges $(50 \%)$ consider evidence is obtained according to international regulations while twenty-six $(37 \%)$ recognize the way it is obtained, violates fundamental rights. The rest of the judges interviewed (13\%) did not give an answer to this question. According to another answer, thirty three of the total of interviewed judges subscribe to the 
fact that evidence is practiced respecting the law protecting human rights, whereas seven officials declared that the direct and cross examinations are not practiced according to the Constitution. The rest of the judges interviewed did not answer this question.

Judges are the officials who perceive and have contact with the counsellors' legal practices. An interpretation of the responses obtained, shows that the mechanisms to gain information regarding the commission of a crime still infringe human rights. It also demonstrates that even though evidence has been obtained illegally, the parties present it in court expecting it to be valued.

Question two. In your experience as a judge, who is the legal representative that more frequently presents illegally obtained evidence?

More than half of all respondents (51\%) replied the prosecutor is more inclined to present pieces of evidence which are in violation of fundamental rights. Seven judges said the defense attorney is the one presenting illegal evidence. Evaluating the particular responses given, the judges' impression is that prosecutors continue to present information obtained through mechanisms that infringe individual rights, suggesting law enforcement agents need to be aware of the consequences of illegal evidence.

Question three. In your practice, do counsellors present illegally obtained evidence for certain crimes more than for others?

Seventy-one percent of the surveyed judges reported that illegal material is presented in court with more frequency for some crimes than for others. Twenty four percent of the surveyed officials said there was not such a pattern in the information presented to Court. The rest of the judges did not give an answer.

Derived from last question we found that the most frequent crimes for which advocates present illegal pieces of evidence are:

GRAPHIC 2

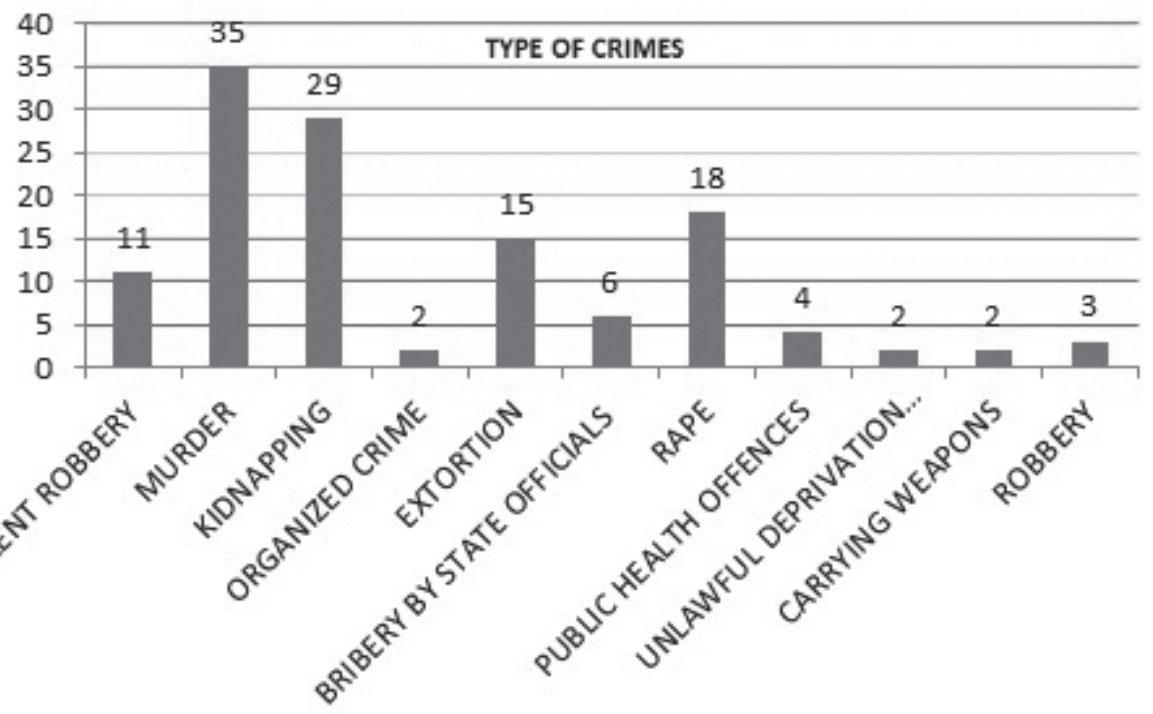


The interpretation of their responses, illustrated in the image, indicate that the criminal investigation authorities employ harsh techniques when trying to discover the authorship of crimes of violence, such as murders and rape. In the case of kidnapping and extortions, they are usually committed by organized crime and Mexican regulations in fact allow wire-tapping and provisional arrest to connect the individuals involved to the crime scene. On the other hand, regardless the fact that murders and rapes are not always perpetrated by gangs, they are considered deep impact offenses and authorities responsible for conducting criminal investigations pursue the lawbreakers and collect evidence using technical but illegal skills.

Therefore, if law prohibits this type of techniques, it is necessary to train agents and personnel on how to investigate potential criminal violations and execute any felony investigative missions without restricting human rights.

Question four. There exists a debate on the weight that must be given to the human rights protection against the criminal investigation and the search for the truth. What should prevail?

\section{GRAPHIC 3 \\ What should prevail?}

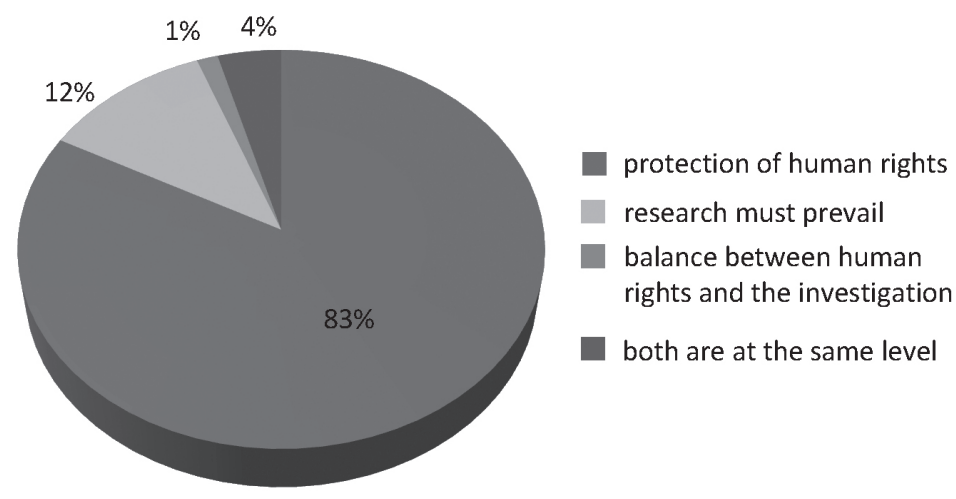

Almost the total number of respondents, that is, fifty eight judges (83\%) indicated that the respect for human rights must prevail over the investigation and the search for the truth. Eight judges (12\%) communicate that criminal investigation is more important than individual rights while one judge $(1 \%)$ answered that there must be a balance between the two of them so that the state does not sponsor lawlessness. The rest of the judges, (4\%) agreed on the fact that none of them should predominate and they should be at the same level. This indicates that the judges' main concern is to adhere to the human right's protection in their decisions.

According to the reported answers, judges that recognize human rights protection should be preponderate include the following aspects in their reasoning: illegality must not be the base of legal procedures, the search of the truth has its limits on law compliance, doing the opposite means that innocent people would be convicted, judges may convict 
people that are not involved with the illegal conduct. The few judges giving more weight to criminal investigation argument that it should prevail in order to promote public security and social peace, that the victim's right to know the truth should not be violated; that search for the truth must be privileged and that justice procurement means that not only the accused rights are protected but also those of the victim.

Results point out that less than ten percent of the judiciary officials give enough weight to victim's rights. This clearly reveals that resolutions will reject illegally obtained evidence without taking into consideration the victim's right to know the truth. The consequence will be lack of punishment to criminals and an inefficient establishment of the facts and circumstances surrounding the criminal activity.

Question five. In your experience, have you observed, excluded or deemed as ineffective a piece of evidence for having been obtained of practiced with no respect for human rights?

Our data shows that ten judicial officers have not considered illegal evidence in trial while eighteen have invalidated them. This research identified that prosecutors and policemen must do their job investigations in accordance with the law, however, based on the respondents' comments, some diligences that are still realized with no respect to individual rights are:

TABLE 2

Respondents reporting criminal investigation activities violating human rights

\begin{tabular}{|l|c|}
\hline \multicolumn{1}{|c|}{ Diligences } & Answers \\
\hline Seizures of personal belongings without warrant & 2 \\
chain of custody that does not meet legal requirements & 1 \\
illegal arrests & 3 \\
\hline Making a statement without defense attorney & 8 \\
Body searches & 1 \\
\hline Confesions and statementes obtained as a result of torture & 3 \\
Biological samples obtained without consent and in absence of defense attorney & 2 \\
\hline People recognition derived from illegal arrests & 1 \\
People recognition without a defense & 3 \\
Torture & 2 \\
\hline Right to defense transgresions & 1 \\
\hline
\end{tabular}

According to the information provided, criminal investigations and legal procedures continue to be conducted without the guarantees enshrined by the Constitution. In this regard, the most recurrent violation that judges have identified is statements o obtained without a defense lawyer whose content must not be admitted within the procedure.

Question six. What would you do if you found an illegal piece of evidence when it turns out to be fundamental to establish the truth? 


\section{GRAPHIC 4}

Judge's reaction to illegally obtained evidence

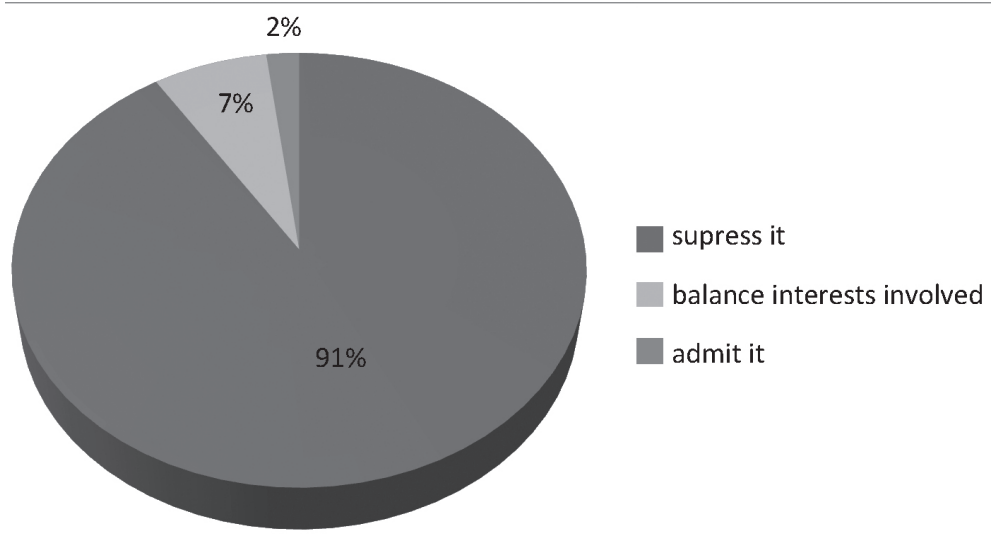

On being asked if they would give value to illegally obtained information, the common answer was that respondents would not consider it to pronounce a guilty verdict. That is, sixty four judges $(91 \%)$ said they would not give value to them. On the other hand, five judges $(7 \%)$ declared they would weigh the situation and consider circumstances involved in the case, one interviewed judge (1\%) answered he would admit the piece of evidence.

We can conclude that generally, judges tend to suppress illegally obtained evidence, giving more importance to the accused's human rights. What judges do not consider is that if this type of evidence is not admitted in trial, it will result in high social costs having in mind that law does not provide with exceptions to the exclusionary rule and as a result, crime will go unpunished.

Question seven. Does the current exclusionary rule regulation appropriately govern this legal institution and the cases it should be allowed in court?

Forty-five judges consider there is an adequate regulation regarding the exclusionary rule whereas twenty-five believe there is not an appropriate regulation. What can be inferred is that after six years of having applied the adversarial system, the common feeling is that the legal provisions do not give guidance to judges and legal counsellors on how to proceed before this complex legal phenomenon.

Question eight. Do you think the exclusionary rule and its exceptions are known by legal counsellors and respected by judiciary officials?

Judges did not give a steady and consistent answer, showing there are doubts regarding the topic. Most judges would suppress illegally obtained evidence even though it was the only trace to find the offender and establish the truth. According to the group of judges interviewed, this type of evidence is often offered by prosecutors in crimes such as robberies, murders and hijacking.

Although forty-five judges argue that there exists an adequate regulation of the exclusionary rule, twenty five judges discuss that the present legislation is not enough and 
there are aspects that need a more discernible guidance. A wide number of judges recognize the lack of exceptions to the exclusionary rule regulations.

Moreover, the findings showed that judges are more interested in the accused's rights than on those of the victim. A few judges admit not having abandoned the inquisitorial model completely and they acknowledge their job is to apply the law even though it is not a reflection of justice.

\section{CONCLUSIONS}

The purpose of this paper was to diagnose the treatment of the exclusionary rule in a Mexican state that has played a pioneering role in the adoption of the adversarial system. With that objective, we studied the law regulating this institution and undertook a perception survey among judicial officials applying the new model of criminal justice.

After the analysis we conclude that:

Despite the fact that the constitution clearly establishes that the injured party has the right to know the truth about the circumstances in which the violations occurred, the new legislation provides for a wider range of rights to the accused that those to the victim and the exclusionary rule prevents certain information to be used to find out the truth.

In Mexico, illegally obtained evidence must always be excluded. With this measure, the individual rights of the accused enjoy a broad protection; however, society will suffer serious consequences since it brings about immunity from punishment. In this sense, the creators of the law were not aware of the social costs involved with this kind of provisions.

A second objective of this analysis was to review and evaluate the legal instruments through the judge's impressions. Pursuant to the survey applied:

According to the information obtained, the legal party that most frequently presents illegally evidentiary material is the prosecutor since the criminal investigation of the legal enforcement authorities continue to violate human rights when facing a violent crime. Additionally, illegally obtained evidence is presented with more recurrence in murders and robberies or in crimes committed by organized crime.

After having studied the subject of analysis, we perceive the obligation of the state to adopt mechanisms to prevent state authorities from undermining human rights. Besides, it is necessary that legal counsellors have a full understanding of the law, followed by its correct application by magistrates.

This survey confirmed the original concept that judges thoroughly respect human rights of the accused, at the expense of the victim's right to obtain the truth. It also showed that judges do not evaluate the specific cases for which they can admit evidence, since they do not respond that they considered the seriousness of the crime before admitting or excluding evidence. Above all, if the established criminal procedure does not guarantee the accused and victim's fundamental rights, it will not strengthen the rule of law and society will not trust the criminal justice system.

There must be more training in order to gain more adherence to and respect for the law. Interpreting the surveyed judges' replies, legal representatives to the parties lack information on illegal evidence showing that there exists an important need of instruction 
about this matter. Under the conditions presented, judicial officials need to be given guidelines on how to achieve both purposes.

Finally, an ambiguous regulation of the exclusionary rule can bring about immunity from punishment and crime must not go unpunished, otherwise it is an invitation to further crimes. Immunity from prosecution is an invitation to further crimes. We conclude with Beccaria's thought that there is no greater incentive for criminals who know that their actions will go unpunished.

\section{CITED BIBLIOGRAPHY}

Ayala, María de Lourdes, et al. (2008): "La reforma al sistema de justicia penal en Nuevo León: sus principales tendencias", México: Institución Renace, A.B.P. pp. 1-396.

BreWER, Stephanie Erin (2014): "Hacia un proceso penal constitucional: Elementos para entender y aplicar la presunción de inocencia en México", Revista del instituto de la judicatura federal, pp. 77-165.

Carriles, Ramón Alejandro (2014): “Tópicos novedosos previstos en el código nacional de procedimientos penales”, Nova Iustiti, 2-8: pp. 94-107.

Cruz Pastrana, Víctor Manuel (2016): Análisis sobre la existencia de presunción de inocencia en la prisión preventiva oficiosa dentro del nuevo sistema de justicia penal en México, (México, Distrito Federal: Universidad Autónoma del Estado de México).

Delgado Carbajal, Baruch (2013): "El sistema penal adversarial acusatorio y oral. Su enseñanza y capacitación en el Estado de México", Nova Iustitia Revista Digital del a Reforma Penal, 1-3: pp. 81-98.

García Ramírez, Sergio (2014): "Comentario sobre el Código Nacional de Procedimientos Penales de 2014”, Boletin mexicano de derecho comparado, p. 47-141: pp. 1167-1190.

LARRAGOITI, Héctor Arturo (2014): "Los nuevos estándares de exigencia para la defensoría pública en el sistema procesal acusatorio y oral", Nova Iustitia. Revista Digital de la Reforma Penal, pp. 2-7: pp. 8-41.

Lecuona, Guillermo (2003): La Investigación de los Delitos y la Subversión de los Principios del Subsistema Penal en México (San Diego: Center for U.S.-Mexican Studies). Retrieved from: http://escholarship.org/uc/item/9wq0x96k. Last visited March 20, 2016.

Lecuona, Guillermo (2011): "Una aproximación hacia la evidencia empírica derivada de la aplicación del principio acusatorio del sistema de juicios orales en México", Letras jurídicas: revista electrónica de derecho (9), pp. 1-18.

Mendoza, Katherine (2011): Aspectos básicos para comprender la reforma constitucional en materia de justicia penal. Cuaderno de capacitación. Clínica para el desarrollo de estudios relacionados con la procuración, administración de justicia, seguridad pública y sistema penitenciario. (México, Distrito Federal: Comisión de Derechos Humanos del Distrito Federal, 18-19). Retrieved from: http://mexicosos.org/descargas/dossier/estudios/aspectos_basicos_para_comprender_la_reforma_constitucional.pdf

Meneses Reyes, Rodrigo \& Quintana, Miguel (2016): "Homicidios e investigación criminal en México", Perfiles Latinoamericanos, Julio-Diciembre, pp. 297-318. 
Meza Fonseca, Emma (2009): "Principio acusatorio y de oralidad en los juicios relativos", Revista del Instituto de la Judicatura Federal, pp. 195-213.

Riego Ramírez, Cristian (2005): Informe comparativo. Proyecto de seguimiento de los procesos de reforma judicial en América Latina. Santiago: Centro de Estudios de Justicia de las Américas.

\section{STATUTES}

Constitución Política de los Estados Unidos Mexicanos. (5/febrero/1917)

Constitución Política del Estado de México (31/octubre/1917)

Código de Procedimientos Penales del Estado de México (28/ marzo/ 1990)

\section{CONVENTIONS}

Declaración Universal de Derechos Humanos (10/diciembre/ 1948)

Convención Americana de Derechos Humanos (22/noviembre/ 1969)

Pacto de Derechos Civiles y Políticos (16/diciembre/1966)

\section{APPENDIX No 1}

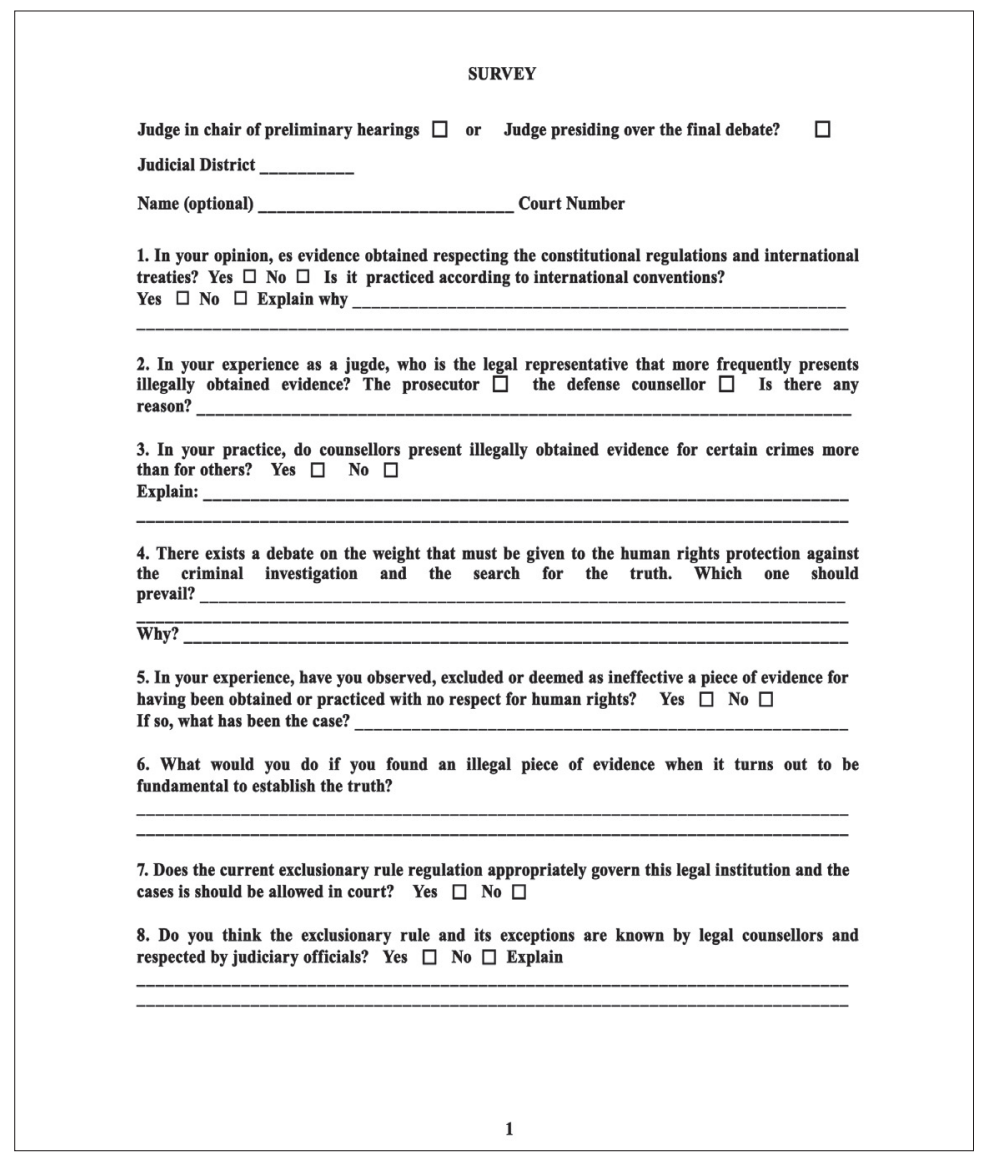


